\title{
Impact of Psychological Empowerment on Employee Performance - A Conceptual Review
}

\author{
*J.N.G. Sreenivas; Assistant Professor \\ Vignan Institute of Technology and Science \\ Vignan Hills, Deshmukhi Village, Pochampalli(M), Nalgonda-508284.
}

\begin{abstract}
Despite decades of extensive research by academicians and rigorous exercises of management practitioners, "Empowerment" construction is incomplete and still facing skepticism. Many leading service companies have dropped the thought of empowerment from their management practices list and some abandoned the idea completely, others still successfully working on this approach into a balanced way of people management strategies to make employee performance effective. Several researchers found positive relationship between empowerment cognition and effectiveness at the level of the individual employee. Given these observations this paper intends to review conceptual evidences on the empowerment effects. "To be empowered people must "feel" empowered. Believing in this idea this paper attempts on psychological perspective because it enables to systematically review both the theoretical and conceptual evidence on the effects of empowerment in the workplace.
\end{abstract}

Key words: Psychological empowerment, Employee performance, Job Satisfaction, Commitment

\section{Introduction}

Today almost all organizations at least at some point of time might have thought about adopting some kind of empowerment initiative for their entire workforce or in some part of their organization. To be successful and eventually to achieve competitive advantage in business environment, companies need critical workforce in terms of creativity, skill, knowledge, ideas, and synergy. In this regard "empowerment" emerged as an important and most preferred management practice, Hence empowerment is not only limited to front line workers but indeed to top level managers in the executive level. But empowerment effects on the work force in different organizations are seen in different ways. (L. Honold-1997). Several authors in several areas found positive relationships between empowerment and effectiveness of individual employee.

\section{Importance of Empowerment of Employees}

Employee empowerment has become a very important issue to organizations producing services. This is because the nature of service delivery particularly the "intangible" dominant services. The customers and the employees are engaged simultaneously in the production of the service. This inseparability is what is considered by the organizations in choosing how best to serve its customers (Fulford and Enz, 1995 M.D. Fulford, C.A. Enz.1995). Several authors found positive relationships between empowerment cognitions and effectiveness at the level of the individual employee. The inability of the management to control the service encounter makes the employees responsible for the quality of service delivered to the customers. In order for the management to trust that the employees are Successful in dealing with their customers it has to give the authority, power, decision making and necessary support to their employees to successfully perform their role and succeed in it, which is referred to as employee empowerment ( Greas ley, N. king, Nicloa 2005). For the purpose these organizations follow either traditional or empowerment approach. Assessing the effects of popular management techniques on firm performance, found that focusing on empowerment has a significant effect on firm's performance and one of the reasons for this is unsatisfied, underpowered workforce.

\section{Methodology}

This paper work is purely based on secondary data and needs further empirical evidences.

\section{Review of Literature}

The psychological perspective is focused on how employees experience empowerment at work? This perspective refers to empowerment as the personal beliefs that employees perform their role successfully in relation to the organization when people are feeling empowered at work, they experience 4 dimensions (Spreitzer's (1995) p; 1444) include...

1) Meaning: Involves a fit between the needs of one's work role and one's beliefs, values and behaviors Eg: The work I do is very important to me. 
2) Competence (self efficacy): Is the belief that an employee is capable of performing work activities with skill. Eg: I have mastered the skills necessary for my job.

3) Self-determination (choice): Is an individual's sense of having control over how work is accomplished choice in initiating and regulating one's actions. Reflects a sense of autonomy. Eg: I can decide on my own how to go about doing my work.

4) Impact: The degree to which one can influence strategic, administrative or operating outcomes at work. Eg. I have significant influence over what happens in my organization.

It is argued that the four cognitions combine additively to create an overall construct of empowerment as "A motivational construct manifested in 4 cognitions" (Spreitzer 1995, p.1444).

Psychological empowerment which takes into account environmental influences should not be confused with individually oriented conceptions of empowerment, which view empowerment as a personality variable (Zimmerman, 1990).

\section{Perspectives of Empowerment:}

Over the last 2 decades 2 complementary perspectives on empowerment at work have been emerged.

1. Social structural Empowerment

2. Psychological Empowerment

\section{Social structural Empowerment:}

It Emphasis on building more democratic type organizations in which power is being shared between superiors and subordinates with the goal of cascading power to lower levels of the organizational hierarchy. In this perspective individuals have formal authority or control over organizational resources and the ability to take decisions relevant to a person's job or role (Journal of organizational Behavior 2004). It is all about employee participation through increased delegation of responsibility down throughout the organizational chain of command.

\section{Psychological Empowerment:}

Psychological empowerment refers to a set of psychological states that are necessary for individuals to feel a sense of control in relation to their work role. Rather than focusing on managerial practices that share power with employees at all levels, the psychological perspective is focused on how employees experience or feel their work. This perspective refers to empowerment as the personal belief that employees have about their role in relation to the organization (Spreitzer, 2007). According to Spreitzer, psychological empowerment reflects an individual's active orientation to his or her work role and consists of cognitions that are shaped by the work environment rather than a fixed personality attribute. Conger and Kanungo (1988) define empowerment as a process to enhance feelings of self-efficacy among employees through the identification of conditions that foster powerlessness and through their removal by both formal organizational practices and informal techniques of providing efficacy information.

\section{Benefits of employee empowerment:}

Empowered employees are engaged employees. In another way, empowerment is a key driver of employee engagement. Empowerment is perceived as a complete solution to highly regulated workplaces where creativity was stifled and workers were alienated, showing discontent both individually and collectively. It is a motivational process of being enabled. Commitment is characterized by a strong belief in and acceptance of the organization's goals and values and a willingness to exert considerable effort on behalf of organization. (Dr. preeti S Rawat, 2012). Studies show psychological empowerment evokes organizational commitment that means a meaningful job provides a suitable fit between requirements and purposes of one's organizational work roles and one's personal value system. A sense of competence gives workers the belief that they are able to perform their work roles with skill and success. Self-determination gives workers control over their work and a choice in work-related decision processes. It enhances involvement in the organization's goals and employees feel more autonomy and control over jobs and enjoy better relationships with superiors (Deci, vallerand and Ryan - 1991). Studies show that organizations which are able to attract and retain employees despite challenging economic conditions have employees involved in decision making process. This is described as structural empowerment. Finally it helps to enhance teamwork performance. Psychological empowerment influences continuance commitment, normative commitment and affective commitment then.

\section{Motivations and Ideology}

NICS- National institute of clinical studies Feb-2003 findings says that large number of factors that operate at different phases, at different levels in the organization and in different combinations to influence performance. Factors include - Goal setting and feedback, Leadership and HRM, climate and culture, 
teamwork, structure, organizational learning and knowledge transfer, T\&D. Performance is dependent on will, focus and capability, yet organizations typically overdevelop capability, and under develop will. (Chen, Gilad; Sharma, Payal Nangia; Edinger, Suzanne K.; Shapiro, Debra L.; Farh, Jiing-Lih-2011). Studies shows that TQM adapted organizations identified a positive correlation between leadership, job satisfaction, customer satisfaction, employee empowerment. The assumption behind job satisfaction is that people are able to balance their specific satisfactions and dissatisfactions and arrive at a general degree of satisfaction with jobs (John Salazar-2006). Salazar believed that personality, gender, family roles, education (individual characteristics) and also job characteristics; organizational characteristics and promotion opportunities (situational characteristics) influence job satisfaction. Herzberg's Motivation-Hygiene theory says that people are more satisfied by elements of the job itself than by the environment. Psychological empowerment of Spreizer(1995) has been used to measure psychological empowerment in a number of empirical studies in the context of service industry has been found that psychological empowerment has a positive impact on job satisfaction (Deci, vallerand and Ryan - 1991).

\section{Organizational Tenure and Psychological empowerment:}

A positive relationship between tenure and job satisfaction suggests that those who fit in an organization are more likely to be satisfied and have longer organizational tenure. Ozaralli, N. (2003). Koberg, Boss, Senjem \& Goodman 1999 argue that employees with greater organisationl tenure are more likely to experience feelings of empowerment. Ozaralli(2003) found that employees who have a longer tenure with their company feel more empowered than those with shorter organizational tenure. It is due to experience i.e. increasing in empowerment related to increased experience. Spreizer 1995 \& Thomas \& Velthhouse 1990 suggest the potential relationship between tenure and psychological empowerment. Cogner and Kanurgo (1988) amd Thomas \& Velthouse (1990) clearly clarified psychological approach to empowerment. Rather than approaching empowerment as "Something managers do to their people" the psychological perspective focuses on perceptual dimensions of empowerment. Thomas and Velthhouse(1990) defined psychological empowerment as intrinsic task motivation. Conger \& Kanurgo (1988) distinguished between four empowerment dimensions relating to employee's orientation to his work. Deci \& Ryan (1991) found that self-determination results in learning, interest in activity and resilience in the face of adversity.

\section{Research on Empowerment:}

Social structural Empowerment findings:

Research on high involvement work practices has been conducted by researchers at the center for effective organizations at the University of Southern California. It focused on organizational level outcomes. This research has shown that high involvement practices which involve sharing power, information, knowledge and rewards with employees at all levels has positive outcomes for organizations in terms of QWL.(Journal of Quality Management-2000)

Psychological Empowerment findings:

Unlike social-structural perspective where many different instruments have been used a single measure of psychological empowerment is used, much of the work on psychological experience of Empowerment has been conducted at the individual level of analysis. In recent times more research has examined team level empowerment in terms of demographics of empowerment, employees with higher levels of education, more tenure, and greater rank report experiencing more feelings of empowerment. Research reveals that when people experience empowerment at work, positive outcomes are likely to occur. When employees experience more empowerment they report less job strain, more job satisfaction and organizational commitment also less likely to leave organization. Psychological empowerment does not only effect employees attitudes (Greas ley, N. King, Nicola 2005). It also affects their performance (productivity) and work behaviors (innovation, upward influence). More empowered teams have better process improvement, higher quality services and more customer satisfaction. Empowered teams are also more proactive, less resistant to change, satisfied with their jobs, committed to their teams and organizations.

In the structural view, employees feel more personal control over their work in terms of performing the job, and also more aware of the business and the strategic context in which the job is performed and more accountable for performance outcomes. These cognitive - affective responses have later been relabeled as "Psychological Empowerment" (conger \& Kanurgo, 1998). Employees experience more psychological empowerment under these conditions.

1. Wider span of control between management and workers

2. Higher accessibility to information about organization's mission and performance

3. Role clarity

4. Supportive organizational cultures

5. Enriching job characteristics 
6. Rewards based on individual performance

7. Where employees feel valued and affirmed

8. Strong work relationships

9. More sociopolitical support from subordinates, peers, superiors and even customers

10. Leaders are approachable and trustworthy.

It is indicating that social - structural empowerment enables psychological empowerment and converse is also true. Employees who experience empowerment at work seek out and shape their work contexts and act to create and sustain work environments that provide social - structural empowerment.

In this review, I focus psychological perspective on empowerment for some reasons, first, the growing consensus on its conceptualization because of major contribution to this by Cogner and Kanurgo(1998) and Thomos and Velthouse (1990) who clarified clearly about psychological approach to empowerment. Second because of the development of a sound and validated measurement instrument (Spreitzer, 1995, 1996). Third it enables us to systematically review both theoretical and conceptual evidences on the effects of empowerment in the workplace.

Rather than approaching Empowerment as "Something managers do to their people"(Quinn \& Spreitzer 1997 p. 41) the psychological perspective focuses on various psychological dimensions of individual's empowerment. Psychological Empowerment is an increased intrinsic task motivation i.e. generic condition by an individual, pirating directly to the task that produce motivation and satisfaction (Thomos and Velthouse 1990). It is distinguished between 4 psychological dimensions, which reflect four distinct cognitions relating to an employee's orientation to his or her work.

\section{Conclusion}

The purpose of this paper is to trace out the evidences of Psychological Empowerment impact on employees' performance. It is now concluding that "To be empowered, people must "feel" empowered. Psychological |Empowerment creates a sense of feeling that employee's experience that they are motivated in their day to day work activities and are given decision making power, having control over the organizational resources and feeling of autonomy. They are engaged workers having less strain and stress, usually capable of more productivity and having more job satisfaction. Psychologically Empowered work force is less likely to leave organization because their normative, affective, continuous commitment towards organization is at its level best. Unlike social structural empowerment, psychological empowerment focuses on "feeling" of employee that makes them to feel motivated in their work. It is indicating that social - structural empowerment enables psychological empowerment and converse is also true. Employees who experience empowerment at work will be expected more to participate in decision making process and can shape their work activities and perform more efficiently and effectively and capable of more production. They create work environments that provide social - structural empowerment.

\section{Selected Bibliography}

1. Conger, J.A. \& Kanungo, R.N. (1998). The empowerment process: Integrating theory and practice. Academy of Management Review, 13, 471-482.

2. Becker, B. E. \& Huselid, M. A. (1998). High performance work systems and firm performance: A synthesis of research and managerial implications. Research in Personnel and Human Resources Journal, 16, 53-101.

3. Kirkman, B. \& Rosen, B. (1999). Beyond self-management: The antecedents and consequences of team empowerment. Academy of Management Journal, 42, 58-71.

4. Lawler, E.E. (1996). From the Ground Up: Six Principles for Building the New Logic Corporation. San Francisco: Jossey-Bass.

5. Lawler, E.E., Mohrman, S.A., \& Benson, G.. 2001. Organizing for high performance: Employee Involvement, TQM, Reengineering, and Knowledge Management in the Fortune 1000. San Francisco: Jossey-Bass.

6. Spreitzer, Gretchen M., \& Quinn, Robert E. (2001). A Company of Leaders: Five Disciplines for Unleashing the Power in your Workforce. San Francisco, CA: Jossey-Bass.

\section{References}

[1]. Chen, Gilad; Sharma, Payal Nangia; Edinger, Suzanne K.; Shapiro, Debra L.; Farh, Jiing-Lih Journal of Applied Psychology, Vol 96(3), May 2011, 541-557.

[2]. John Salazar-Journal of "Human Resources in Hospitality and Tourism" Volume 5, Issue1, 2006_Accepted: 1 Mar 2005, Published online: 22 Sep 2008.

[3]. Deci, vallerand and Ryan -motivation and education, "Educational Psychologist", Volume 26, Issue 3-4, 1991.

[4]. Journal of Quality Management, Volume 5, Issue 2, $3^{\text {rd }}$ quarter2000. 
[5]. Spreitzer, G. M. (1995). Psychological empowerment in the workplace: Dimenstions, measurement, and validation. Academy of Management Journal, 38(5), 1442-1466.

[6]. Ozaralli, N. (2003). Effects of transformational leadership on empowerment and team effectiveness. Leadership \& Organization Development Journal, 24(5/6), 335-345.

Koberg, C. S., Boss, R. W., Senjem, J. C., \& Goodman, E. A. (1999). Antecedents and outcomes of empowerment. Group and Organization Management, 24(1), 71-91.

Thomas, K. W., \& Velthouse, B. A., (1990). Cognitive elements of empowerment. Academy of Management Review 15(4), 666681.

[7]. Zimmerman, M. A. (1990). Taking aim on empowerment research: On the distinction between individual and psychological conceptions. American Journal of Community Psychology, 18(1), 169-177.

[8]. Zimmerman marc A American journal of community psychology Vol. 23, No. 5, 1995

[9]. NICS - National Institute of clinical studies, Literature review series. Feb - 2003.

[10]. Journal of organizational Behavior Vol. 25, Issue 8, December 2004, 955-968.

[11]. Dr. Preethi S Rawat IJSSH (2012) Vol. 2(1) 65-69.

[12]. L. Honold "A review of the literature on employee empowerment", "Empowerment in organizations" 1997, Vol. 51(:4), PP 202212.

[13]. K. Greas Ley, N King, Nicola. "Employee perceptions of empowerment". "Employee relations" 2005 Vol 27(4); $354-368$.

[14]. D. Collins. Rooting for empowerment? Empowerment in organizations 1995, Vol 3(2): 25-33.

[15]. Sprizers; (2007) The hand book of organizational Behaviour, Sage Publications.

[16]. Fulford and Enz, 1995 M.D. Fulford, C.A. Enz The impact of empowerment on service employees Journal of Managerial Issues, 7 (2) (1995), pp. 161-175

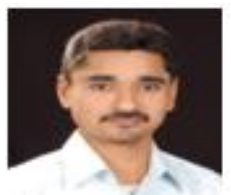

J.N.G. Sreenivas is pursuing Ph.d from Vignan University, Vadlamudi, Guntur, Andhra Pradesh in "Empowerment of Employees". Completed M.B.A.with specialization in Marketing and HR from CNK Reddy college, Bangalore, Affiliated to Bangalore University, in 2001 and B.com from Ideal degree college, Kakinada, Andhra Pradesh in 1999.

Currently working as an Assistant Professor in MBA Department at Vignan Institute of Technology and Science, Deshmukhi, Hyderabad.

Areas of research interest include Motivation, Leadership, T \& D, QWL, and Organizational Development. 